\title{
Analysis of Prescribing Phase in Prescription of Pulmonary Tuberculosis Outpatients at Regional General Hospital in Jakarta in 2018
}

\author{
Farnia Zahra $^{1}$, Azrifitria ${ }^{2 *}$, Ganda E. M. Tampubolon ${ }^{3}$ \\ \{farniazhr16@gmail.com ${ }^{1}, \underline{\text { azrifitria@uinjkt.ac.id }}$, ganda_erikson@yahoo.com ${ }^{3}$ \} \\ *corresponding author \\ Pharmacy Study Program, Faculty of Health Sciences, UIN Syarif Hidayatullah Jakarta, Ciputat, \\ 15419, Indonesia ${ }^{1,2}$, Regional General Hospital Tarakan, Jakarta, Indonesia ${ }^{3}$
}

\begin{abstract}
Based on PERMENKES No. 72 of 2016 about Pharmaceutical Service in Hospital, this study aimed to determine percentage of patient characteristics, completeness, and accuracies in prescriptions on pharmaceutical and clinical aspects to improve the quality of tuberculosis treatment. A retrospective descriptive study was conducted on 211 pulmonary tuberculosis prescriptions with a purposive sampling method in pharmacy service at a Regional General Hospital in Jakarta from January to December 2018. Most characteristics of patients were male, 26-35 years old, new patients classification, first category tuberculosis treatment, and complete treatment results were $64 \%, 23 \%, 92 \%, 92 \%$, and $90 \%$, respectively. The completeness in pharmaceutical aspects such as dosage form and drug strength were on $51 \%$ and $37 \%$, respectively. Accuracies in clinical aspects were $93 \%$ for both dose accuracies and frequency of drug administration. Last, there was $2 \%$ of drug duplication. Collaboration between physicians and pharmacists plays a significant role in ensuring patient safety and the quality use of medicines.
\end{abstract}

Keywords: Clinical aspect; Pharmaceutical aspect; Prescription; Pulmonary tuberculosis

\section{Introduction}

Based on the Minister of Health Regulation No. 72 of 2016, prescribing activities include administration, pharmaceutical suitability, and clinical considerations on prescription. Prescription services start from receiving prescriptions until giving medicine to patients with providing information. Pharmacists should play a central role carefully in each stage of the prescription service flow to prevent medication errors. Currently, medication errors have become one of the health problems that cause many health problems from mild to severe, which is death [1]. Medication errors affect such as detrimental to the patient due to drug use during the handling of health personnel, which can be prevented [2]. There are four phases in medication errors are prescribing errors, transcribing errors, dispensing errors, and administration errors $[3]$.

Tuberculosis is in the third position disease with the highest death rate in the world [4]. Tuberculosis cases in the world continue to increase, in 2017 India was in the first rank of 
tuberculosis incidence which reached 2.700 .000 cases, followed by China with 889.000 cases, and Indonesia with 842.000 cases [4]. In 2018, the total tuberculosis sufferers in Indonesia increased to 845.000 cases and reached a prevalence rate of 316 of 100.000 population, making Indonesia in the third position of highest tuberculosis cases in the world [5].

A study of medication errors at a Tertiary hospital in Central Jakarta that was conducted by Bilqis [6], reported that for the drug aspect study, there was $32.8 \%$ of prescriptions have incorrect drug doses and $8,5 \%$ of administration error then there is $49.2 \%$ of drug interactions. High prevalence of tuberculosis case in one of the regional general hospital in Central Jakarta, the hospital where the research was conducted has been an interesting focus of prescription study because there isn't any research about this yet and to know if medication errors especially in pharmaceutical and clinical aspects become one of the reasons behind high cases of tuberculosis in this hospital.

\section{Method}

This was a retrospective and descriptive study. This study was conducted of 211 pulmonary tuberculosis outpatient prescriptions, medical records, and tuberculosis 01 forms with purposive sampling method in pharmacy service at a Regional General Hospital in Jakarta from January to December 2018. A total of 211 samples were processed for patient characteristics and because of limitation due to pandemic, only 59 samples were obtained from prescriptions and medical records processed for analyzing medication errors in pharmaceutical and clinical aspects. Institutional Ethics Committee permission from the hospital was obtained (No.004/KEPK/RSUDT/2020). Pharmacist, pharmacist assistants, and pulmonologist were included in this study. Inclusion criteria in this study were pulmonary tuberculosis in outpatients, outpatients who returned their prescriptions to the pharmacy service in this hospital, both 17 years old and older patients. The error classification system used in this study was based on the regulations set by the Ministry of Health Regulation number 72 from 2016 concerning the Standards of Pharmaceutical Services with slight modifications. This study aimed to determine percentages of patient characteristics, completeness, and accuracies in tuberculosis treatment prescriptions in prescribing stages of drug administration on pharmaceutical and clinical aspects. Pharmaceutical aspects: dosage form and drug strength. Clinical aspects: dose accuracy, frequency of drug administration, and drug duplication.

\section{Result}

\section{Sociodemography \\ Gender}

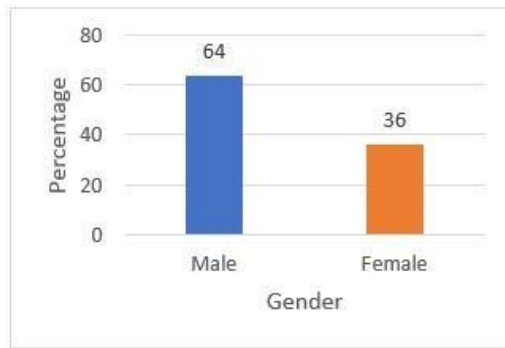

Fig.1. Patient's gender percentage 
From 211 samples, the patient's gender were female and men present on $36 \%$ and $64 \%$, respectively. Based on that data, men cases higher than female. This data aligned with Afidayanti [7] which obtained from 58 medical records $53 \%$ of it were male.

Age

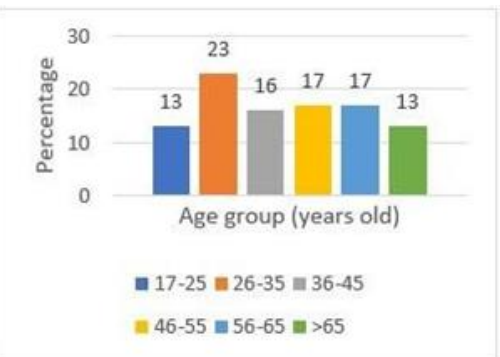

Fig.2. Patient's age group percentage

From figure 2 ages were present in group 17-25, 26-35, 36-45, 46-55, 56-65, > 65 years old in $13 \%, 23 \%, 16 \%, 17 \%, 17 \%, 13 \%$ respectively. The highest in $26-35$ years old, this data aligned with Camila's [8] research with obtaining that age group patient dominant in 15-55 years old $(76,36 \%)$.

\section{Classification of patient based on previous treatment}

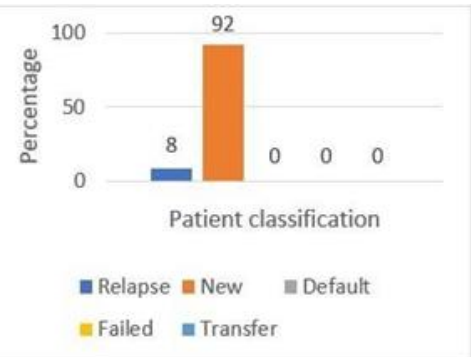

Fig.3. Classification of patient based on previous treatment percentage

From the figure 3 , there are 2 classifications patient based on previous treatment was namely relapse and new were present at $8 \%$ and $92 \%$, respectively. This data aligned with Prananda [9] which obtain patient tuberculosis in his research were new patient, relapse, and failed on $80 \%, 16 \%$, and $4 \%$, respectively.

\section{Treatment Categories}




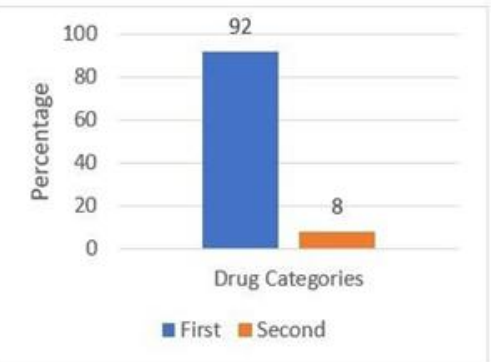

Fig.4. Patient's treatment categories percentage

From the figure 4 , there are two tuberculosis treatment category which category 1 and category 2 were in $92 \%$ and $8 \%$, respectively.

\section{Treatment result}

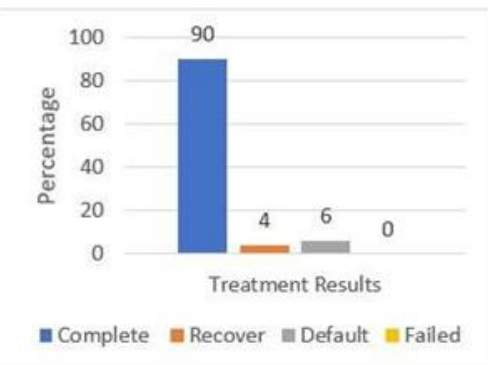

Fig.5. Patient's treatment result percentage

From the figure 5, there are 3 treatment results were complete treatment, default, and recover $90 \%, 6 \%$ and $4 \%$ respectively.

\section{Pharmaceutical Aspects}

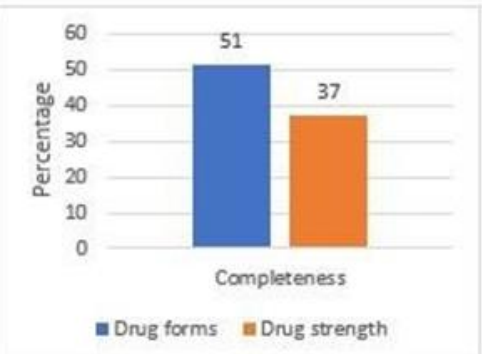

Fig.6. Completeness of pharmaceutical aspect percentage

From figure 6, the pharmaceutical aspects for dosage forms and drug strength completeness at $51 \%$ and $37 \%$, respectively. The incompleteness of dosage forms and drug strength $49 \%$ and $63 \%$, respectively. 


\section{Clinical Aspect}

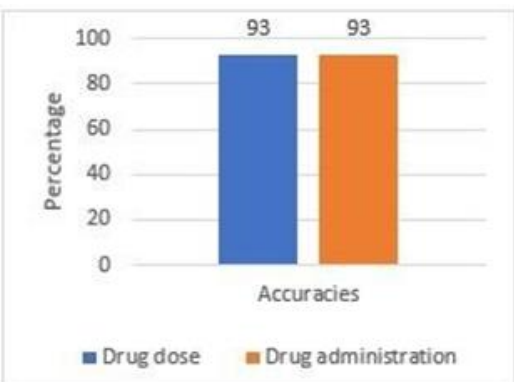

Fig.7. Accuracies of clinical aspect percentage

From figure 7, the clinical aspects include accuracies of drug dose and frequency of drug administration were present both $93 \%$, for the inaccuracies of drug dose and frequency of drug administration both $7 \%$.

\section{Drug Application}

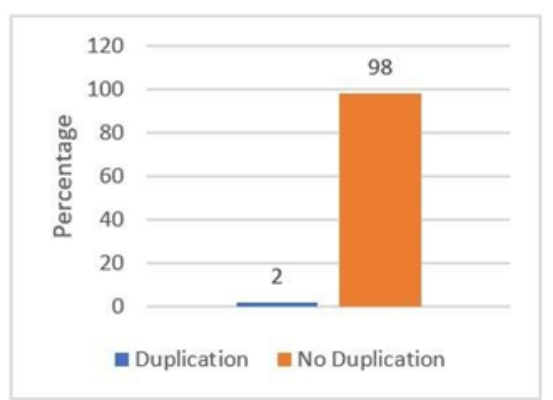

Fig.8. Presence of drug duplication percentage

From figure 8 , there were $2 \%$ of drug duplications. The results showed the duplication of the drug in 1 prescription namely pyridoxine $2 \times 10 \mathrm{mg}$ and lesichol 2 × $300 \mathrm{mg}$ because the content of lesichol consists of lecithin (ppc 95\%) $300 \mathrm{mg}$, vitamin B1 $6 \mathrm{mg}$, B2 $6 \mathrm{mg}$, B6 (pyridoxine) $6 \mathrm{mg}, \mathrm{B} 126 \mathrm{mg}$, vitamin E $10 \mathrm{mg}$ and nicotinamide $30 \mathrm{mg}$.

\section{Discussion}

\section{Sociodemography}

From 211 samples, we can conclude that patient's gender dominant by $134(64 \%)$ males then 77 females $(36 \%)$. One of the reasons why most men suffer from tuberculosis because they have smoking habits that cause a high risk of tuberculosis. A study showed that tuberculosis patients who smoke as much as $32 \%$ [10]. Smoking will mess the mucociliary as it can make defects on the body immune, macrophage response, dendritic cells, and natural killer cells thus increasing the risk, subdistrict, and duration of infection [11,12].

According to one study, pulmonary tuberculosis tends to be higher in men than females 
due to its exposure and a higher level of susceptibility than females [13]. Professions in men such as farmers, drivers, rickshaws, and taxi drivers where it requires more force than female living at home such as housewives work so that men are more likely to be exposed to tuberculosis germs [14].

Females have a stronger immune response to antigenic challenges such as infection and vaccination than men have. It is mediated mostly by sex hormones that play a role in tuberculosis, supported by the fact that in men sex hormones do not appear until puberty. Sex hormones have a variety of effects on various types of immune cells including B cells, T cells, neutrophils, dendrite cells, macrophages, and natural killer cells. While there have been no direct studies to show this, there are many supportive aspects that the immune response to tuberculosis can be modified from sex hormones. Male and female sex hormones can affect the function of immune cells in ways that may be relevant to Mycobacterium $[15,16]$

The Age group of 26-35 years old is a productive age to work or produce something for themselves and others. Productive age is prone to tuberculosis due to a large number of interactions with others who may have been exposed and high mobility. This leads to the possibility of transmitting or contracting from others [17]. The Ministry of Health [2] stated that about $75 \%$ of tuberculosis patients are the most economically productive age group (15-54 years old). The second-highest rate of age group with tuberculosis is 46-65 years old group where there is a decrease in endurance and the condition is more susceptible to diseases, especially infectious diseases, one of which is tuberculosis [18].

New cases are patients who have never been treated with tuberculosis drugs or have already ingested tuberculosis drugs for less than a month, relapsed patients are patients who have previously received tuberculosis treatment and have been declared recover or complete treatment but re-diagnosed with positive Acid Resistant Basil, default patient has been treated and given treatment but then haven't done treatment in 2 months later or more with positive Acid Resistant Basil before the treatment period is complete, failed patients are patients whose phlegm test results remain positive or return to positive in the fifth month or during treatment and the transfer case is the patient who is transferred to another register to continue his treatment [19]. People with pulmonary tuberculosis with positive Acid Resistant Basil test results (+) are the main source of transmission. At the time of coughing or sneezing, the sufferer spreads germs into the air in the form of a droplet. Droplets containing germs can stay in the air at room temperature for several hours. A person diagnosed with tuberculosis with positive Acid Resistant Basil can transmit at least 10-15 others each year [20].

The first treatment category consists of 2(HRZE)/4(HR)3 used by new patient classification, positive Acid Resistant Basil pulmonary tuberculosis patients, negative Acid Resistant Basil with positive thorax result, and extra pulmonary tuberculosis patients. The second treatment category consists of 2(HRZE)S/(HRZE)/5(HR)3E3 used for previously treated positive Acid Resistant Basil patients, relapsed patients, failed patients, and patients with treatment after breaking up (default) [19].

The complete treatment is a patient who has completed its treatment in full but no results of the re-phlegm examination on the last treatment and one previous examination or a patient who has completed his treatment in full but does not complete the requirements of curing or failing. Recover is a patient that has completed its treatment in full and the follow-up examination results already negative on the last treatment and one previous examination. Default is a patient who is not been treated for 2 months in a row or more before the treatment period is complete [19]. 


\section{Pharmaceutical and Clinical Aspects}

The presence of drug strength is necessary for the prescription so there won't be any errors in the administration for the patient. The drug supply will be used by the patient according to the needs, circumstances, and condition of the patient. The same drug can have more than one drug strengths e.g. lansoprazole has a dosage strength of 15 and $30 \mathrm{mg}$, there are dosage strengths of $50 \mathrm{mg}, 100 \mathrm{mg}$, and $200 \mathrm{mg}$, then domperidone there are a dosage strength of 10 $\mathrm{mg}$ and $5 \mathrm{mg} / 5 \mathrm{ml}$ in the form of syrup or suspension, then ambroxol dosage strengths are 30 $\mathrm{mg}, 15 \mathrm{mg} / 5 \mathrm{ml}$ in syrup form [21] The strength of the dosage is important because it relates to the dosage of the drug as well as the drug forms. But for the regulation in this General Hospital, if there's no presence of drug strength, so it means the smallest drug strength that available.

Another important thing is to write the drug form because the drug can have more than one form and it adjusts the patient's need. For example, ambroxol has more than one form, namely tablets and syrups. Another example of a drug that has more than one the available drug is acetylcysteine there are syrups, tablets, and capsules then curcuma can be in the form of tablets or syrups. Last, for pyridoxine there are tablet and syrup options [22]. In this hospital, pyridoxine only available in form of a tablet. The reason behind a high percentage of the incompleteness in drug forms because if the drug form is a tablet, it is usually not written on the medical records or on prescription. The tuberculosis drugs themselves already have complete pharmaceutical aspects.

The dose of a drug is the number of drugs that can be used or given to a patient both to be used as medicine inside and outside [23]. Dose accuracy is necessary for the effects of the drug to be achieved. The determination of the dose for tuberculosis drugs is determined from the patient's weight because the effects of the drug itself are affected by the patient's condition. As for tuberculosis patients according to this hospital formulary, for weight less than $40 \mathrm{~kg} \mathrm{R} / \mathrm{H} / \mathrm{Z} / \mathrm{E}$ 300/300/750/750, 40-60 kg R/H/Z/E 450/300/1000/1000 and weights above $60 \mathrm{~kg} \mathrm{R} / \mathrm{H} / \mathrm{Z} / \mathrm{E}$ 600/400/1500/1500 (R= Rifampin, H= Isoniazid, Z= Pyrazinamide, E= Ethambutol). As for FDC or Fix Dose Combination is also based on weight. For weight less than $38 \mathrm{~kg}$ FDC 1x2 tab, 38$55 \mathrm{~kg} 1 \times 3$ tabs and more than $55 \mathrm{~kg}$ FDC 1 x 4 tabs. For the tuberculosis drugs it already have a $100 \%$ clinical aspects accuracies.

The error of dosing is one prescription containing duplication of vitamin B6, in the prescription written vitamin B62 x $10 \mathrm{mg}$ and lesichol $2 \times 300 \mathrm{mg}$. The content of lesichol consist of lecithin (ppc 95\%) $300 \mathrm{mg}$, vitamin B1 $6 \mathrm{mg}$, B2 $6 \mathrm{mg}$, B6 $6 \mathrm{mg}$, B12 $6 \mathrm{mg}$, vitamin E $10 \mathrm{mg}$ and nicotinamide $30 \mathrm{mg}$. Duplication of vitamin B6 passes the maximum dose $(5-20 \mathrm{mg} / \mathrm{day})$ [27]. Furthermore, in other prescriptions there is the administration of curcumin $1 \times 5$ tab where according to the literature of curcmin administration is $1 \times 1-3$ tab and in the last 2 recipes, there is the administration of lesichol $2 \times 300 \mathrm{mg}$ where according to the literature of the administration of lesichol is $3 \times 1-2$ soft capsules [22]. However, from the hospital formulary dose administration of the above drugs are correct. Dosing should also refer to the patient's condition.

According to figure 7 accuracy of the frequency of administration of the drug amounted to $93 \%$. This result is said to be correct because it is in line with Bilqis' research [6] which obtained the accuracy of the frequency of drug administration $91.5 \%$ and has been said to be appropriate. On the prescription written lesichol 2 × $300 \mathrm{mg}$ where according to the literature the frequency of use of lesichol $300 \mathrm{mg}$ is $3 \times 1-2$ soft capsules. Lesichol is a useful drug to maintain liver function where one of the side effects of anti-tuberculosis drugs namely isoniazid, rifampin, and pyrazinamide can interfere with liver function [2]. But for the frequency of drug administration written in this hospital formulary shows that the frequency 
of administration of the drugs are appropriate.

According to figure 8 , there was $2 \%$ for drug duplication. Duplication of treatment is a double dose of treatment or the same drug but through different administration routes [24]. The results showed there were drug duplication in 1 prescription namely pyridoxine $2 \times 10 \mathrm{mg}$ and lesichol $2 \times 300 \mathrm{mg}$ because the content of lesichol consists of lecithin (ppc 95\%) $300 \mathrm{mg}$, vitamin B1 $6 \mathrm{mg}$, B2 $6 \mathrm{mg}$, B6 $6 \mathrm{mg}, \mathrm{B} 126 \mathrm{mg}$, vitamin E $10 \mathrm{mg}$ and nicotinamide $30 \mathrm{mg}$. Duplication of therapy in addition to wastage can also lead to increased risk of toxicity of patients, especially hepatotoxic [25]. However, for pyridoxine which includes water-soluble vitamins, it is never in a state of toxicity in the body because this excess vitamin will be secreted through urine [26]. Consideration of administering lesichol with pyridoxine can also be based on the patient's condition which makes it possible to get additional doses.

\section{Limitations of Research}

Because of the lack samples due to the Covid-19 outbreak makes it impossible for researchers to visit hospitals, the samples obtained were samples before the Covid-19 outbreak.

\section{Conclusion}

In sociodemography aspects, most characteristics of patients were male, 26-35 years old, new patients classification, first category tuberculosis treatment, and complete treatment results were $64 \%, 23 \%, 92 \%, 92 \%$, and $90 \%$, respectively. The completeness in pharmaceutical aspects such as dosage form and drug strength were on $51 \%$ and $37 \%$, respectively. Accuracies in clinical aspects were $93 \%$ for both dose accuracies and frequency of drug administration. Last, there was $2 \%$ of drug duplication. The highest incorrect data is drug strength presence on $63 \%$ and the highest correct aspects are accuracies in drug dose and frequency drug administration on $93 \%$.

In tuberculosis drug aspects, this hospital have complete accuracies and presence in pharmaceutical and clinical aspects. The electronic prescription service especially in tuberculosis treatment in this hospital in 2018 has been said to be appropriate. For better result need more samples. Collaboration between physicians and pharmacists play a significant role in ensuring patient safety and the quality use of medicines.

\section{References}

[1] Oktarlina, R. Z., \& Wafiyatunisa, Z.: Kejadian Medication Error pada Fase Prescribing di Poliklinik Pasien Rawat Jalan Rumah Sakit Daerah Mayjend HM Ryacudu Kotabumi. Fakultas Kedokteran Universitas Lampung, 1(3), 540-545 (2017)

[2] Kementerian Kesehatan Republik Indonesia: Permenkes tentang Kesehatan Masyarakat RI NO. 75 (2014)

[3] Khairurrijal, M. A. W., \& Putriana, N. A. Review: Medication Error Pada Tahap Prescribing, Transcribing, Dispensing, dan Administration (2018)

[4] WHO: Tuberculosis in South-East Asia Region, Retrieved February 1 2020. Accessed from https://www.who.int/southeastasia/health- topics/tuberculosis (2018)

[5] WHO: World Health Statistic Report 2018. World Health Organization, Geneva (2019)

[6] Bilqis, S. U: Kajian Administrasi, Farmasetik dan Klinis Resep Pasien Rawat Jalan di Rumikital Dr. Mintohardjo pada bulan Januari 2015, Jakarta (2015)

[7] Afidayanti, E.Evaluasi Penggunaan Obat Antituberkulosis pada Pasien Tuberkulosis Paru Periode 
Tahun 2016-2017 (Studi dilakukan di Puskesmas Pamotan Kecamatan Dampit Kabupaten Malang). Malang (2018)

[8] Camila,O.J. Evaluasi Penggunaan Obat Antituberkulosis Pada Pasien Tuberkulosis Paru Dewasa Di Instalasi Rawat Jalan Balai Besar Kesehatan Paru "X" Tahun 2011. Surakarta (2013)

[9] Prananda. Evaluasi penggunaan obat anti tuberkulosis paru pada pasien dewasa rawat jalan di unit pengobatan penyakit paru-paru (up4) pontianak. Program Studi Farmasi, Fakultas Kedokteran, Universitas Tanjungpura, Pontianak (2011)

[10] Ismah, Z., \& Novita, E: Studi Karakteristik Pasien Tuberkulosis Di Puskesmas Seberang Ulu 1 Palembang. Unnes Journal of Public Health, 6(4), 218-224. https://doi.org/10.15294/ujph.v6i4.15219 (2017)

[11] Wijaya AA.: Merokok dan tuberkulosis. Jurnal Tuberkulosis Indonesia. Accessed from: http://ppti.info/ArsipPPTI/PPTI-Jurnal-Maret 2012.pdf (2012)

[12] PDPI: Pedoman Diagnosis dan Penatalaksanaan Penyakit Paru Obstruktif Kronis (PPOK) di Indonesia (2013)

[13] Masniari, Priyatini, Aditama TY.: Faktor-Faktor yang Mempengaruhi Kesembuhan Penderita TB Paru. J Respir Indo. 257: 176-185 (2007)

[14] Nurkumalasari, N., Wahyuni, D., \& Ningsih, N: Hubungan Karakteristik Penderita Tuberkulosis Paru dengan Hasil Pemeriksaan Dahak di Kabupaten Ogan Ilir. Jurnal Keperawatan Sriwijaya, 3(2), 5158 (2016)

[15] Fish, E. N.: The X-files in immunity: Sex-based differences predispose immune responses. Nature Reviews Immunology, 8(9), 737-744. Accessed from https://doi.org/10.1038/nri2394 (2008)

[16] Marais, B. J., Gie, R. P., Schaaf, H. S., Hesseling, A. C., Obihara, C. C., Starke, J. J., Enarson, D. A., Donald, P. R., \& Beyers, N.: The natural history of childhood intra-thoracic tuberculosis: A critical review of literature from the pre-chemotherapy era. International Journal of Tuberculosis and Lung Disease, 8(4), 392-402 (2004)

[17] Nurkumalasari, N., Wahyuni, D., \& Ningsih, N.: Hubungan Karakteristik Penderita Tuberkulosis Paru dengan Hasil Pemeriksaan Dahak di Kabupaten Ogan Ilir. Jurnal Keperawatan Sriwijaya, 3(2), 51-58 (2016).

[18] Muchtar, N. H., Herman, D., \& Yulistini, Y.: Gambaran Faktor Risiko Timbulnya Tuberkulosis Paru pada Pasien yang Berkunjung ke Unit DOTS RSUP Dr. M. Djamil Padang Tahun 2015. Jurnal Kesehatan Andalas, 7(1), 80. Accessed from https://doi.org/10.25077/jka.v7i1.783 (2018)

[19] Kementerian Kesehatan Republik Indonesia: Pedoman Nasional Pengendalian TuberkulosisKeputusan Menteri Kesehatan Republik Indonesia Nomor 364. Kementerian Kesehatan Republik Indonesia, PengendalianTuberkulosis,110 (2011)

[20] Adiatama.: Pengobatan tuberkulosis, diagnosis, terapi dan masalahnya (2013)

[21] Badan Pengawas Obat dan Makanan (BPOM) Republik Indonesia 2014: Pusat Informasi Obat Nasional (Pionas). BPOM RI. Accessed from http://pionas.pom.go.id/monografi/ambroksol (2014)

[22] Aberg, J. A., Lacy, C. F., Amstrong, L. L., Goldman, M. P., \& Lance, L. L.: Drug Information Handbook. edisi 17, 3401 (2009)

[23] Ardhitantri, F: Identifikasi Drug Related Problems Instalasi Rawat Jalan Bagian Anak Rumah Sakit Islam Surakarta Periode Januari. Skripsi (2008)

[24] Aslam, M., Tan, C.K., dan Prayitno, A.: Farmasi Klinis (Clinical Pharmacy), Menuju Pengobatan Rasional dan Penghargaan Pilihan Pasien. Jakarta: Elex Media Komputindo (2003)

[25] Yasin, N. M., Sunowo, J., \& Supriyanti, E.: Drug Related Problems (DRP) dalam pengobatan Dengue Hemoragic Fever (DHF) pada pasien pediatri. Majalah Farmasi Indonesia, 20(1), 27-34 (2009)

[26] Triana, V.: Macam-Macam Vitamin Dan Fungsinya Dalam Tubuh Manusia. Jurnal Kesehatan Masyarakat, 1(1), 40-47 (2006)

[27] Médecins Sans Frontières: Essential Drugs - $\quad$ Practical Guideline. Accessed from https://medicalguidelines.msf.org/viewport/EssDr/english/pyridoxine-vitamin-b6-oral16684535.html (2020) 